\title{
Dynamic Extension Class
}

National Cancer Institute

\section{Source}

National Cancer Institute. Dynamic Extension Class. NCI Thesaurus. Code C91272.

A class created by the Dynamic Extension computer program. 